\title{
Carrying Death Away: Social Responsibility, The Environment and \\ Comedy in Terry Pratchett's Johnny and the Dead
}

\author{
Michelle de Villiers ${ }^{\mathrm{a}}$ \\ a Department of English, University of Pretoria, South Africa, rabubee@gmail.com
}

\begin{abstract}
$\underline{\text { Abstract }}$
Terry Pratchett is well known for his personal brand of comic fantasy (both in his adult and children's novels) which he uses to underscore more serious and pertinent concerns. His use of the comic and fantastic are platforms from which to voice his criticisms of society and the way it functions. In Pratchett's own words (in accepting the Carnegie Medal), 'humour has its uses. Laughter can get through the keyhole while seriousness is still hammering on the door. New ideas can ride in on the back of a joke, old ideas can be given an added edge' (Pratchett, 2001:n.p.). With this in mind then, the aim of this article is to analyse Terry Pratchett's Johnny and the Dead (1993) in terms of its didactic purpose and aims to educate child readers about environmental issues and social responsibility. The paper will focus on Pratchett's use of comic fantasy as a platform from which to voice his criticisms of society and its attitude toward the environment. The paper also considers how Pratchett uses both comedy and fantasy to distance readers from their 'Primary Realities' (the reality in which they live and function on a daily basis) by transporting them into a Secondary Reality (i.e. the world of the book) which contains emotional truth that transcends physical reality (Elgin 1985:33).
\end{abstract}

Key words: Johnny Maxwell, comedy, fantasy, environment, Primary and Secondary reality, didactic, children's literature, Johnny and the Dead, Terry Pratchett 
In his book, Of Other Worlds (1966:34), C.S. Lewis states that "“when I was ten, I read fairy tales in secret and would have been ashamed if I had been found doing so. Now that I am fifty, I read them openly. When I became a man I put away childish things, including the fear of childishness and the desire to be very grown up"". Lewis addresses an important point here which all researchers of children's literature must take into consideration. This is that children's literature is sometimes seen primarily as the occupation of children and not something in which adults and especially academics should take an interest. In fact, when adults and academics do take an interest, it is seen as 'childish', as Lewis explains, and the topic is considered unworthy of academic study. However, as this article attempts to show, children's literature can have a profound influence on children's development of self and can assist children in being more aware of their position in society. As such, children's literature has a vitally important didactic function which, as Sheila Egoff (1981) explains, attempts to educate children about certain moral issues and social values. Children's writing, she says, in any genre, has tended towards being a mirror of the reigning social concepts and conditions of the day, the didactic function of which has been described as 'stronger than any that has occurred in the history of adult literature' (Kaye, 1980:142). The aim of this article then, is to analyse one of Terry Pratchett's children's books, Johnny and the Dead, in terms of its didactic purpose of educating its child readers about environmental issues and social responsibility. The book is the second instalment in Pratchett's Johnny Maxwell trilogy and has been chosen for its overt didacticism as well as Pratchett's use of comedy for didactic purposes. However, before the analysis can be presented, it is important to first briefly outline some of the theory of children's literature and comedy that has been used in the analysis.

Maria Nikolajeva (2005:xi), one of the preeminent researchers of children's literature, maintains that all literature, both adult and children's, is an art form and a 'didactic, or rather 
ideological, vehicle'. It is simply that the 'ideological, or pedagogical intention is often more explicit in children's literature'. But, this concerns 'grade', not 'nature' (Nikolajeva, 2005:xii). The more explicit nature of children's literature, as Nikolajeva (2005:xvii) goes on to argue, has led many readers to view it as an inferior form of literature. However, it still has much in common with mainstream adult literature. '[I]t reflects, albeit indirectly, our own reality; it conveys ideological values; it has strong potential to affect the mind; and it also appeals to our emotions.' Critics may view children's literature as subordinate due to its historical and social context, its strong educational associations and its implied audience, but Nikolajeva (2005:xvii) strongly maintains that it is not in any way inferior to adult literature, it is merely different. If this idea is accepted, then critics must accept that children's literature has an aesthetic of its own, which needs to be studied in order to gain a sense of how it functions and how it affects its readers. And so, as mentioned previously, the aim of this article is to provide an analysis of Pratchett's use of the children's fantasy novel as well as comedy to comment critically on environmental issues.

Pratchett uses his personal brand of comic fantasy (both in his adult and children's novels) as a platform from which to voice his criticisms of society and the way it functions. Pratchett's humour and fantasy thus function to underscore more serious and pertinent concerns by distancing readers from their 'Primary Realities' (the reality in which they live and function on a daily basis) by transporting them into a Secondary Reality (i.e. the world of the book) which contains truth that extends beyond the bounds of the real (Elgin 1985:33). But how does comedy do this?

According to John Young Thomson Greig (1969:70), laughter and therefore also comedy, provide for the release of excess 'psycho-physical energy' by allowing for a momentary 'weakening' of any difficulties which cause psycho-physical energy to generate in the first place. Grotjahn (in Corrigan, 1965:275) provides further clarification by 
explaining that the purpose of comedy is to allow us to communicate freely with our unconscious, which in turn allows us to gain 'strength for this reality we live in'. Communication with our unconscious allows our 'imagination' and 'intuition' to be kept active, young and alive. This 'relief theory' is the idea that laughter is the release of 'nervous excitement' or 'emotional tension' (Bardon in Charney, 2005:468). Bardon goes on to say that the relief theory may also have something to do with Darwin's survival theory. Laughter and comedy allow for the release of tension, and these result in less tension being built up within societies, which, in turn, allows for stabilisation and prosperous development.

Comedy allows us to see reality as it is, and so, if we are perceptive enough to realise this fact, we will be able to look upon our reality with more understanding. What is most important for this article, however, is the function of comedy as a distancing mechanism (i.e. it transports readers from their primary realities into a secondary reality). Sypher (in Corrigan, 1965:37) explains that comedy is an act in which we remove the masks we use to deal with the world around us. Through comedy, people are thus allowed to unmask themselves, to 'come out for a moment, from behind the facade of their "serious" selves', the 'selves' required of them by society (Sypher in Corrigan, 1965:37). When we eventually put our masks back on, or return to our 'personae', we enter in to them with new understanding and with a new perspective of the duality of our existence - our 'real', unmasked and uninhibited selves, versus our socially bound, masked and wary selves. When this laughter takes place we feel we are able to conquer the stress and anxiety we feel about the world around us. 'Unflinching and undaunted we see where we are. This strengthens us as well as society' (Sypher in Corrigan, 1965:53).

The purpose of the comedy of 'earlier times', according to Corrigan (1965:11), was to see into the comic. Nowadays, however, the comic is used to see into the serious. In Corrigan's own words, 'the comic has become a transparency through which we see to the 
serious'. According to Christopher Frye (in Corrigan 1965:15), '[c]omedy is an escape, not from truth but from despair....In tragedy we suffer pain; in comedy pain is a fool, suffered gladly'. Frye goes on to say that '[1]aughter may seem to be only like an exhalation of air, but out of that air we came; in the beginning we inhaled it; it is truth, not a fantasy, a truth voluble of good which comedy stoutly maintains'.

It is clear then that comedy is a very useful tool for providing a criticism of society. But what is important to consider is why writers like Pratchett might choose to use comic children's literature as a platform from which to launch serious observations. Lathey (in Reynolds, 2005:58), for example, questions whether parents would not want to protect their children from this disturbing subject matter such as war, violence, and for this article, specifically death, for as long as possible, even though it has become an accepted and even common theme in children's literature. But protecting children from realities of the degradation of the environment has become an exceedingly difficult task (Lathey in Reynolds, 2005:59). Storr (1971:146) explains that due to the rise of television and radio, children are exposed to topics and issues of the adult world and so absorb 'the prevalent attitudes' towards these topics long before they can read. Storr maintains that providing children with knowledge of good and evil allows them to deal with the knowledge and make it tolerable.

Significantly, Pratchett's commentary in these novels is also channelled through the voice of his child protagonist, Johnny. The result is to develop a more complex apprehension on the reader's part; rather than present neatly-parcelled truths, the author allows both his protagonist and the reader to struggle towards self-realized insights. His child characters, although naïve and innocent, often act in profoundly perceptive ways serving as tools by which Pratchett explores difficult subject matter. By voicing his criticisms through child characters, Pratchett converts his commentary into simple and easily understandable remarks 
and explanations. This makes it possible for Pratchett to focus on a multitude of concerns in his Johnny books, ranging from divorce to death. Furthermore, Elgin argues that child readers are transported into a Secondary Reality when reading and it is possible to argue that contained within this 'other reality' is a truthfulness that surpasses the physical (Elgin 1985:33). Pratchett is able to use this emotional reality to make pain, fear, and death, which are part of the physical world, come alive. If children characters are able to defeat this fear, pain and death in the Secondary Reality (the world of the book), then perhaps child readers will also believe they are able to do so in their Primary Reality (the world in which they live).

Johnny and the Dead is the second book in Terry Pratchett's trilogy about the young Johnny Maxwell, the first being Only You Can Save Mankind (1992) and the third, Johnny and the Bomb (1996). The books do not form part of Pratchett's Discworld series and are aimed at a broad readership aged between six and twelve. All three books recount the various adventures of Johnny, the books' protagonist and unlikely hero, and his friends Wobbler, Yoless, Bigmac and Kirsty. In Johnny and the Dead, Johnny Maxwell sets out on a mission to save the local cemetery owing to his ability to see and speak to the dead. This discovery is made as the result of dare from Wobbler to knock on the door of a mausoleum belonging to the deceased Alderman Thomas Bowler (1822 - 1906). The Alderman, to Johnny's surprise responds to his knock and this sets in motion a series of events that lead to Johnny's bonding with the dead (buried in the cemetery). Johnny's discussions with the Alderman and the other dead ignite his unrelenting curiosity which then goads him into learning more about the dead buried in Blackbury's cemetery as well as the history of his hometown. The time spent in the cemetery makes Johnny realise how beautiful the grounds are, a poignant realisation since the city council has sold the cemetery to a development company, United Amalgamated Consolidated Holdings, which has plans to uproot the dead to build on the grounds. The dead soon find out about these plans and, horrified, ask Johnny for his help to save their home. 
Recalling the use of children's literature to make didactic comments about society, it is interesting to note the use of comedy in Johnny and the Dead to talk about ecological issues. Comedy, as discussed in detail before, has the ability to distance readers from a text and in doing so, it may also influence the way people think about a text or life in general. Comedy can therefore have an important role to play in today's society, especially with the increasing pressure to be more aware of the environment. It is a good thing then that, according to Don Elgin (1985:1), the genre of comedy can influence people to be more ecologically minded as comedy provides a mirror from which humanity can create a perception of itself. Elgin (1985:3) uses the term 'literary ecology' to describe the idea that literature can both create and reflect attitudes that people hold about nature. To underscore his argument, Elgin refers to Weiss:

\begin{abstract}
Man, whatever else he be, is a part of nature. So his artistic world cannot be one of sharply demarcated opposition to his natural world, but rather must be viewed as a fluid and continuous extension of his domain as ordinary member of animate nature - subject to all the limitations of biological reality, into a realm of unreality of his making, stripped of those limitations. And since artistic endeavour is thus a direct organic outgrowth of nature, its elements are, of necessity, the same as those of primitive biological experience.
\end{abstract}

(Weiss in Elgin, 1985:29)

With this in mind, Johnny and the Dead can be seen as functioning within the realm of 'literary ecology' as it exposes readers to a more ecologically-minded point of view. The driving force behind this message is the fact that the Blackbury community is brought together by their concern for the cemetery, the 'only open space for miles' (Dead 17). The concept of community is a typical feature of comedy. But one can perhaps define 'community' in two ways. Firstly, in terms of a social community (the coming together of people with a similar mindset) and secondly, in terms of society's communion with nature 
(the inextricable union we have with nature). As such, the concept of 'community' functions doubly in supporting the ecological agenda.

According to Elgin (1985:16), there are three basic assumptions of comedy that make it the perfect mechanism for a discussion of ecology. Firstly, comedy is a confirmation and a celebration of life. This function can also be termed a 'Carrying Away of Death', which, according to Sypher (in Elgin, 1985:16), is a triumph over mortality by some 'absurd faith in rebirth, restoration, and salvation'. If comedy functions to carry death away, it is interesting then that Blackbury is only linked to nature or any sort of environment by the graveyard. Although the cemetery is a place where death, or at least the idea of death, is most prominent, it is, ironically, a place of life as it allows for a greater understanding of oneself and as such, offers to make valuable contributions to the living. The cemetery is therefore a place that has the ability to 'carry death away' since it allows for the remembrance of the dead which means that the dead never truly die since society keeps them alive in their memories. In this way, Pratchett subverts the expected connotations of graveyards as places of death. In addition, Pratchett's treatment of the dead allows for comedy, and if comedy is a celebration of life, the cemetery's function as a place of life is doubly reinforced. Furthermore, the cemetery is the only green space in Blackbury for miles, and so its ecological function becomes intertwined with its social function. Pratchett's comment on the dead as an important part of society thus extends to a comment about the function of the cemetery as a site of ecological importance. Johnny is the first to realise this when he hears of the news to build on the cemetery:

Johnny looked at the cemetery. It was the only open space for miles. "I'd have given them at least a pound," he said.

"Yes, but you wouldn't have been able to build things on it," said Wobbler. "That's the important thing."

"I wouldn't want to build anything on it. I'd have given them a pound just to leave it as it is."

(Dead 17) 
The humour here lies in the fact that the land has been bought for such a low price, but the poignancy of the dialogue lies in Johnny's willingness to pay more for the land to remain as it is. The second idea that Elgin (1985:18) posits as important to the comic tradition and its use for environmental commentary is the idea that humans are a part of nature and must adapt to it, rather than believe it must adapt to them: 'comic humanity' never considers itself as greater than nature. Although humanity may use the laws of nature for its own benefit, it can only do so to the extent that the system remains in balance since balance is needed for the system to survive. Therefore, comic humanity seems to sustain the struggle for gaining personal freedom within the system. But humanity must return the system to its original form once a disturbance has taken place. Pratchett exploits this function of comedy, the 'comic humanity', in order to complement the function of the Secondary World (i.e. the world of the book). And so, child readers are removed from their Primary Worlds not only for the purposes of identity, but also to understand the purpose of balance by confirming the return of the system to a state of stability through which our own chances for success are enhanced.

And so, the intrusion of the Secondary World into the Primary initially functions as a type of disturbance in the Primary Reality of Johnny and the Dead. However, this intrusion may also function to highlight the more obvious disturbance within the Primary World itself, that is, the neglect of the cemetery which represents the 'environment' as a whole. This disturbance is made clear by Wobbler's comment about the cemetery: “"[m]y dad says this is all going to be built on. He said the Council sold it to some big company for fivepence because it was costing so much to keep it going"' (Dead 17). This can also be seen in the following comment about the space surrounding the Joshua Che N'Clement building (Bigmac's apartment building): '...it had been built in the middle of a huge area of what was theoretically grass ("environmental open space"), but which was now the home of the 
Common Crisp Packet and Hardy-Perennial Burned-Out Car' (Dead 40). Interesting to note is the presentation of the cemetery as far less menacing or threatening than the Joshua Che N'Clement building. In creating this contrast between the apartment building and the cemetery, the function of the cemetery in representing life rather than death is once again highlighted.

Furthermore, the function of the cemetery as representative of the environment can be seen by Johnny's comment early on in the book:

"A lot of people come for walks here," said Johnny. "I mean, the park's miles away, and all there is there is grass. But this place has got tons of bushes and plants and trees, and, and - "

"Environment," said Yo-less.

“And probably some ecology as well," said Johnny.

(Dead 44)

The two boys clearly do not understand what 'ecology' means and use it more as the buzz word which it has become in recent years which Pratchett uses to undermine the overt didacticism of the book. However, what is clear from this conversation is that the boys do understand the difference between a patch of earth covered with grass and a true, living and natural environment. The boys may not understand why the cemetery as a natural environment is so important, but they seem to have a vague understanding of the importance of the cemetery as an open space.

The cemetery, is the only natural space in Blackbury, and so forms a romantic landscape in which the 'real and the symbolic meet' (Saunders, 1993:1). Saunders (1993:23) explains that Classical mythology needed a landscape or location in which humans and the supernatural could meet. The forest became this place and retained its supernatural link even after the intrusion of Christianity into the classical world. In addition, the term 'forest' 
originates from the Latin term foris which means 'outside' (Saunders:1993:1). Taken in the context of Johnny and the Dead, the cemetery, functioning as 'the forest', is literally 'outside', but it also functions 'outside' Primary Reality. In other words, the cemetery - the forest - is the Secondary World, or at least the plane which allows for the intrusion of the Secondary World.

Saunders explains that the word 'forest' also envelops the Greek and Latin terms for forest, hyle and silva respectively, which were associated with 'disorder, chaos and primordial matter'. This links to Mendlesohn's idea that the Secondary World is a world that creates disorder in the Primary Reality. In a similar vein, the cemetery sets the scene for transformation. This transformation allows for change since once characters enter into the 'forest', they are removed from their Primary Realities (Saunders, 1993:103). As such, 'the forest becomes a landscape of delight, escape and marvel, the counterpart of the court and the essential part of the knight's existence' (Saunders, 1993:113).

And so, the Secondary World intrudes into the Primary and further disrupts it, making Johnny and the rest of Blackbury realise the importance of the cemetery in terms of its ecological value. Once this realisation has been achieved, the dead can leave as balance has once again been restored. This restoration of balance takes place at the very end of the book, once the dead have finally left the cemetery:

The cemetery was already looking more lived-in. There were endless arguments between the Volunteers who wanted it to be habitat and the ones who wanted it to be ecology and a middle group who just wanted it to be clean and tidy, but at least it was wanted, which seemed to Johnny to be the most important thing.

(Dead 228)

Elgin's third assumption is that comedy avoids 'abstractions' because, at the heart of most comic characters, are the 'common sense, humility, and acknowledgment that one 
belongs to a larger system whose survival is essential to the survival of individual members' (Elgin, 1985:55). Although the comic may often present humanity as 'foolish', 'smelly', 'pretentious' or 'lecherous', it also presents people as 'compassionate' and caring in response to 'the accumulation of experience' (Elgin, 1985:21).

The 'foolishness' and 'pretentiousness' of which Elgin speaks is clearly presented in Johnny and the Dead as humanity's self-importance is made visible in the way in which the Blackbury community treat each other and their surroundings. The most obvious example of this is the community's neglect of the cemetery:

For the first time he really began to notice the cemetery... In front was the Cemetery Road, which had once had houses on the other side of it; now there was the back wall of the Bonanza Carpet Warehouse. There was still an old phone box and a letter box, which suggested that once upon a time this had been a place that people thought of as home. But now it was just a road you cut through to get to the bypass from the industrial estate.

(Dead 32)

Elgin's proposition that the comic often presents humanity as 'foolish' and 'pretentious' functions to make a comment about the environment, since the world functions as an antagonist to the environment (Elgin, 1985:19-20). Nature's survival is essential to the survival of the individual members (which includes humanity) (Elgin, 1985:21). However, there are further examples of degradation within the community itself that speak of its pretentiousness on a social level. A prime example of this is the description of the Joshua Che N'Clement block of flats: '[i]f you had to be somewhere frightening when it got dark, Johnny thought, the Joshua N'Clement block rated a lot higher on the Aaargh scale than any cemetery. At least the dead didn't mug you' (Dead 39). This can further be seen in the in the following description:

Often the Blackbury Guardian had pictures of people complaining about the damp, or the cold, or the way the windows fell out in high winds...or the way gangs roamed its dank passageways and pushed 
shopping trolleys off the roof into the Great Lost Shopping Trolley Graveyard. The lifts hadn't worked properly since 1966. They lurked in the basement, too scared to go anywhere else...no one liked the Joshua Che N'Clement block. There were two schools of thought about what should be done with it. The people who lived there thought everyone should be taken out and then the block should be blown up, and the people who lived near the block just wanted it blown up.

(Dead 40)

The 'compassion' and sympathy of which Elgin speaks, however, can be seen at the end of the book when the community bands together in order to protect what they have finally come to realise, with the help of Johnny and his friends, about the historical, social and ecological importance of the cemetery. The clearest example of this banding together can be seen straight after the council meeting when the community starts to gear itself up for social changes:

"And then we ought to do something about the High Street," said someone.

"And get some decent playgrounds and things again, instead of all these Amenities all over the place."

"And blow up the Joshua N'Clement and get some proper houses built $-"$

"Yo!" said Bigmac.

"Here here," said Yo-less.

Mr Atterbury waved his hands calmly.

"One thing at a time," he said. "Let's rebuild Blackbury first. We can see about Jerusalem tomorrow."

"And we ought to find a name for ourselves!"

"The Blackbury Preservation Society?"

(Dead 159)

A further example of the community's joining forces can be seen in the following dialogue:

"Exciting day, isn't it? You started something, eh?" [said Mr Atterbury]. 
"Didn't mean to," said Johnny, automatically. Things were generally his fault.

"It could go either way," said Mr Atterbury. "The old railway site isn't so good, but...things look promising, I do know that. People have woken up."

"That's true. A lot of people."

"... [United Amalgamated Consolidated Holdings] are a bit shifty but we might win through. It's amazing what you can do with a kind word."

(Dead $188-189)$

From this dialogue and from the action the community takes to save the cemetery and the rest of Blackbury, Pratchett shows that people are not solely pretentious and selfabsorbed. In fact, Pratchett reinforces Elgin's idea that at the very core of humanity is actually 'compassion' and care. All humanity seems to need is a nudge in the right direction or to be made aware of the possible negative influence that disunity can have. As Hoy (in Elgin 1985:18) states:

Comedy imposes, then, an acceptance of life, which implies as well an acceptance of man. And to accept man, one must be prepared to forgive the weakness, the treachery, the downright depravity which, in spite of man's best intentions, are inherent in his behaviour....That is why comedy, again and again, emphasizes the need for man to undeceive himself about the limitations of humanity, to see life for what it is, and to make the best of it.

It is clear then why Pratchett has chosen the comic genre to strengthen his commentary on ecological awareness. Working in tandem with this ecological awareness is a social awareness, which seems to stem naturally from an awareness of the environment. In working to protect the cemetery, the community of Blackbury also bands together as a 
society in which various other social issues are given light. And so comedy with its natural inclination towards social bonding is an obvious choice for such social commentary.

\section{$\underline{\text { References }}$}

Charney, M. (ed.). 2005. Comedy: A Geographical and Historical Guide. Vol. 1 and Vol. 2. Westport, CT: Praeger. Chesterton

Corrigan, R.W. 1965. Comedy: Meaning and Form. San Francisco, CA: Chandler.

Egoff, S.A. 1981. Thursday's Child: Trends and Patterns in Contemporary Children's Literature. Chicago, IL: American Library Association.

Elgin, D.D. 1985. The Comedy of the Fantastic: Ecological Perspectives on the Fantasy Novel. Westport, CT: Greenwood Press.

Greig, J.Y.T. 1969. The Psychology of Laughter and Comedy. New York, NY: Cooper Square.

Kaye, M. 1980. The Critical Front. In Bator, R. (ed.). 1983. Signposts to Criticism of Children's Literature. (pp. 142 - 146). Chicago, IL: American Library Association.

Lathey, G. 2005. Autobiography and History: Literature of War. In Reynolds, K. (ed.). Modern Children's Literature: An Introduction (pp. 58 - 73). New York, NY: Palgrave Macmillan

Lewis, C.S.1966. Of Other Worlds: Essays and Other Stories. London: Geoffrey Bles.

Nikolajeva, M. 2005. Aesthetic Approaches to Children's Literature. Lanham, MD: Scarecrow.

Pratchett, T. 1992. Only You Can Save Mankind. New York, NY: HarperCollins.

Pratchett, T. 1993. Johnny and the Dead. London: Corgi.

Pratchett, T. 1996. Johnny and the Bomb. London: Corgi. 
Pratchett, T. 2001. Speech by Terry Pratchett winner of the CILIP Carnegie Medal. http://www.carnegiegreenaway.org.uk/pressdesk/press.php?release=pres_terspeach.htm. Accessed: 6 July 2013.

Reynolds, K. 2005. Modern Children's Literature: An Introduction. New York, NY: Palgrave Macmillan Saunders

Storr, C. 1971. Things that Go Bump in the Night. In Tucker, N (ed.). 1976. Suitable for Children? Controversies in Children's Literature (pp. 143 - 152). Sussex: Sussex University Press.

Sypher, W. 1956. The Meanings of Comedy. In Sypher, W. (ed.). 1956. Comedy. New York, NY: Double Day Anchor 